\title{
The Love-Lyrics of Arnaut Daniel and Dante
}

\section{Leissa Gordon}

Critics have much discussed the mention that Dante makes of the Provençal poet, Arnaut Daniel, in his masterpiece, The Divine Comedy. It is in the Purgatorio that Dante allows his literary predecessor, Guido Guinicelli, to praise Daniel's fine qualities as a poet.

"O brother," said he, "He who is singled by My finger (he pointed to a spirit in front) Wrought better in the mother-tongue than $I$. Whether in verses of love or prose romaunt He surpassed all; and let the fools contend Who make him of Limoges of more account. To rumour rather than to truth they bend Their faces, fixt in their opinion's seat Ere art or reason they can apprehend. Thus many an elder did Guittone treat, Shouting as one, their votes for him to pledge, Till truth, with most, conquered the counterfeit."1

In the same manner that Dante (who wrote a mere hundred years after Arnaut Daniel) seems to utilize and extend the traditional Provençal theme of the "lauzengiers" with their harmful "becs" at the end of this passage, he also tends to fashion his concept of love as a more highly 
intellectualized version of that of the Provença1 poets in general and Arnaut Daniel in particular. Dante's approbation of Daniel's work can no doubt enlighten the scholar who wishes to consider the influence of the Provençal poet upon the development of Dantean versification and rhyme scheme. However, another area of study which must not be neglected is the comparison of the vision of the two poets regarding their thematic concerns. At what point does Dante depart from the thematic tradition established by Provençal poets such as Daniel and expand his literary consciousness in order to add a new and sanctified dimension to the old theme of the troubadour's love for his lady? It is in his La Vita Nuova that Dante explores the very question of his poetic dedication to love itself. Thus, this work can serve as a point of reference in the endeavor to compare the love-lyrics of Arnaut Daniel with those of Dante.

Since both Arnaut Daniel and Dante are concerned with the same theme, their attitudes toward this theme must be examined. For Arnaut Daniel, love is personified and, subsequently, takes the shape of an all-powerful ruler, a feudal lord to whom the poet owes service.

\section{Anc ieu non 1'aic, mas ella m'a totz temps en son poder amors, et fai m-irat, let, savi, fol, cum cellui $q^{\prime}$ en re no-s torna.}

$$
\text { (No. 58, 11. 1-4) } 2
$$

The poet asserts that he is completely given over to love and, thus, must allow love to control his emotional state. Dante takes much the same attitude, but his personification is extended to the point of actually employing the image of love as a noble lord. The significance of this visual representation is heightened by the fact that it 
appears in the first poem of La Vita Nuova.

When 1o! Love stood before me in my trance; Recalling what he was fills me with horror. He held my heart; and in his arms there lay My lady in a mantle wrapped, and sleeping. (p. 32) ${ }^{3}$

For Dante, it is love who actually possesses the beloved as well as the desires of the lover. What is surprising concerning Dante's attitude toward the personnage that he has created and in whose service he remains, is that the poet feels it necessary to justify his personification of his theme later in the work. Interestingly enough, his justification also involves the justification of his writing in the vernacular, and he credits the Provençal poets by commending their choice of writing about such a worthy subject in the "langue d'oc." The fact that Dante refers to the jongleurs of Southern France during his attempt to prove the efficacy of his personification of this major theme, and yet, does not cite that the personification of love had already been instituted by some of those same poets, indeed borders on the astonishing. It is clear that Daniel uses this poetic technique, although with less of an actual physical implication, in the lines previously cited and, in addition, he has even been known to address his famous master. "Amors, gara,/sui ben vencutz" (No. 57, 11. 35-6). Perhaps Dante felt that he had to justify the personification because of the physical imagery he creates to accompany it. For he does point out:

That I speak of love as if it were a bodily thing, and even as if it were a man, appears from these three instances: I say that I saw him coming; now since 'to come' implies 
locomotion and, according to the Philosopher, only a body in its own power is capable of motion from place to place, it follows that I classify love as a body. I say also that he laughed and that he spoke, with things are appropriate to a man, especially the capacity to laugh; and so it follows that I make love out to be a man.

(pp. 72-3)

The personification that both Daniel and Dante employ in their poetry illustrates the power possessed by a spiritual force such as love. Daniel often emphasizes this spiritual power which he believes reigns over the spiritual or emotional aspects of the lover as well as over his physical qualities. He says, "[Ämors, ]. . fai moirat, let savi, fol: (No. 58, 1.3). But elsewhere he also subtlety expresses that love's dominion includes the body as well as the heart. "de mi pot far 1'amors qu'ins el cor m'intral mieils a son vol c'om fortz de freval vergua" (No. 59, 11. 23-4). In fact, Daniel sees love's influence over the spiritual and physical activities of the lover as two inseparable realms which love habitually governs. "1'amora qu'ins el cor mi pluou/mi ten caut on plus iverna" (No. 56, 11. 13-4). Dante's attitude toward love's power differs from that of Daniel in that he sees love as receiving its power from the imagination. Moreover, Dante chooses to ignore love's domain over the physical desires of the poet and to concentrate on its ability to inspire reason in the mind of the lover. Dante the lover is concerned with the emotional and mental impact of love whereas Daniel views the emotional and physical aspects as being most important. Compare the following lines by Dante which underline the two aspects of the poetlover, his soul or reason and his heart or desire, with the lines by Daniel cited above. 
The soul then of the heart inquires, 'Pray, who Is this who would our intellect beguile?

And is his virtue such as to exile

Al1 other contemplation from our view?'

The heart replies: 'O meditative soul,

This little spirit, newly sent by Love,

Its longings and desires before me brings. (p. 94)

Although love is capable of producing such a debate between reason and desire, it is reason which must prevail. ". . . . my heart began to repent sorrowfully of the desire by which it had so basely allowed itself to be possessed for some days against the constancy of reason" (p. 94). Dante expresses this sentiment because he has momentarily allowed himself to become infatuated with another lady after Beatrice's death. Love, however, prevails and allows his reason to overcome what he considers his "evil desire." It is at the end of La Vita Nuova that Dante expresses his belief in the universality of love and in its power as a governing force in the universe.

Beyond the widest of the circling spheres A sigh which leaves my heart aspires to move. A new celestial influence which Love Bestows on it by virtue of his tears Impels it ever upwards.

This extension of love's influence is not found in the poetry of Arnaut Danie1. It is, instead, Dante who has raised love to the level of the heavens and who, in so doing, sanctifies its power.

But where is the position of the lover in this universe? Both Daniel and Dante seem to be aware of a peculiar type of tension which works on the lover both externally and internally. The poet-lover must live constantly in limbo. He may not openly exhibit his love for the object of 
his desires, but neither can he deny a love which continuously provokes him from within. This theme concerning the struggle which the lover must undergo, partially in order to protect the name of his lady from being revealed, is emphasized by Daniel in his poem, "Anc ieu non 1'aic."

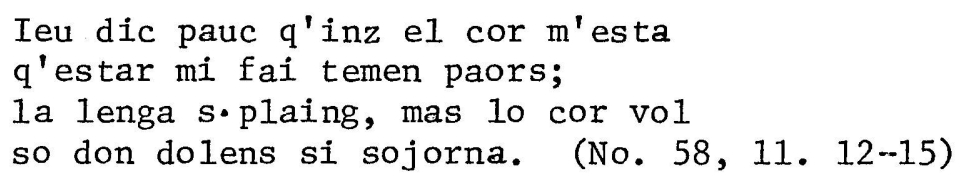

The fact that the lover cannot allow his physical appearance and actions to correspond to his emotional state forces him to be even more dependent upon his love. Daniel is reduced to imploring love to come to his aid in this manner.

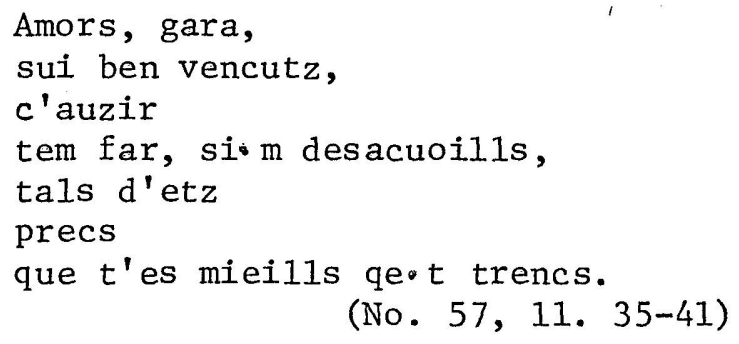

Dante, on the other hand, seems to be more resigned to existing in such an ambivalent state-perhaps because he diminishes the ambivalence by subduing the external reality of his emotions and, thus, forcing them to be highly internalized.

And I, now poor,

Lack even words, and know not what to say. And so, like those who secretly endure, Their needs concealing from the light of day, In aspect gay, Within my heart I pine and grieve the more. (p. 36) 
It is the internalization of Dante's emotion which accounts for his subtlety of style, his exploration into various aspects of what love really is, and his dependence upon his love itself to inspire him to write poetry.

In the case of both poets, the degree of the internalization of the love naturally serves to establish a certain rapport with the beloved. The relationship which the poet sees as ideal concerning himself and his lady depends on to what extent the poet can create an interior world in which his love can exist unharmed. For Arnaut Daniel, the creation of such a milieu is extremely difficult because of the physical relationship into which he would enter, if at all possible, with his lady. His complaints are not merely laments dealing with the sorrow which a powerful emotion such as love may produce. Instead, he grieves when he does not see a promise of sexual success with the beloved.

Del cors $1 i$ fos, non de 1 'arma, e cosentis m'a celat dinz sa cambra. Que plus me nafra 1 cors que colp de vergua, Quar lo sieus sers lai on ill es non intra. (No. 59, 11. 13-16)

One is quite safe, then, to assume that Daniel is sensitive to the "internal-external" struggle chiefly because he dares not be indiscrete and alienate his lady by revealing his relationship with her to others. In addition, within Daniel's own realm of existence the love creates an increased tension because of his own sexual needs and desires. Thus, the object of the poet's affection is not only a poetic creation, but a very real person who must exist physically apart from the poem.

Dante's interior world enables him to achieve such a highly developed concept of love 
that, in effect, Dante does not need the presence of a Beatrice to assure the existence of such a love. On the contrary, he indicated as early as the second chapter of La Vita Nuova that since he first saw Beatrice when they both were children, her image always remained in his mind (p. 30). Furthermore, the poet insists that, in spite of what one who does not understand may speculate, his love is not one dependent upon the fulfillment of a sexual desire. There is, however, a progression in Dante's treatment of the relationship between him and his beloved Beatrice. Although the vision of Beatrice's beauty remains in Dante's mind, during the first part of La Vita Nuova he experiences an intense desire to see her physically.

If I did not lose my wits and were confident enough to reply to her, I would tell her that as soon as I imagine her wonderful beauty the desire to see her takes possession of me, and this desire is so powerful that it utterly destroys anything in my memory that might rise up against it; that is why my past sufferings do not restrain me from trying to see her. (p. 50)

Later, however, Dante acknowledges the fact that his greatest joy takes place when he praises this worthy person (chapter XIII). After Beatrice's untimely death, Dante refuses to choose another lady as the object of his love poetry in spite of the fact that he comes in contact with one who appears to be quite noble and worthy of affection (chapter XXXIX). In the final poem of the book, Dante's vision of Beatrice transcends the exterior world, and by reaching inward to the depths of his own consciousness, he is able 


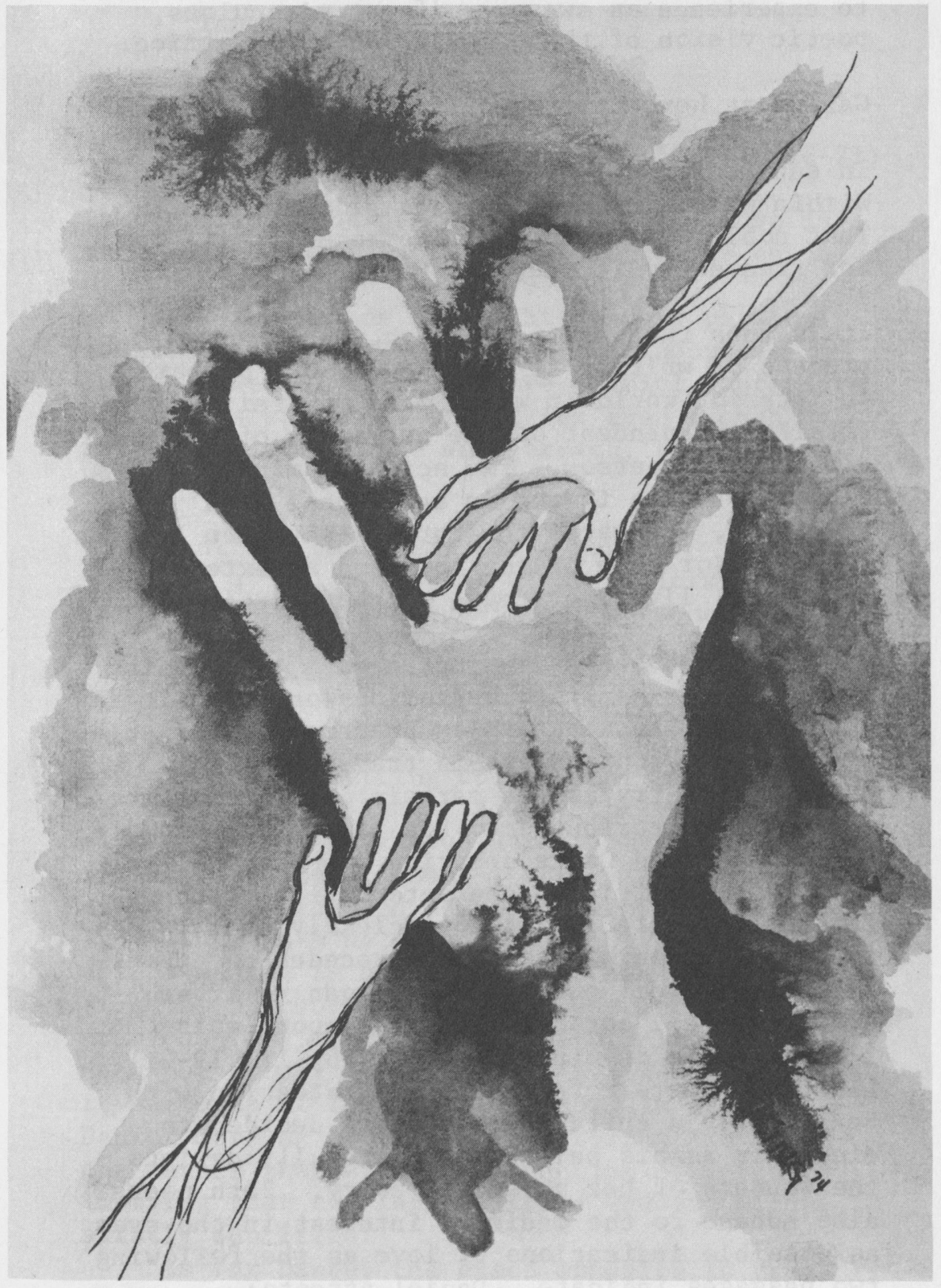


to experience an awesome, if not miraculous, poetic vision of the beloved soul of Beatrice.

Gazing at her, it [my pilgrim spirit] speaks of what it sees

In subtle words I do not comprehend Within my heart forlorn which bids it tell. That noble one is named, I apprehend, For frequently it mentions Beatrice. (p. 99)

It is thus that Dante, through the strenuous process of writing La Vita Nuova, has prepared an interior world in which love may reign totally independent of the necessity of loving a particular person. The actual naming of Beatrice, which is not in accordance with tradition, indicates the total separation between the interior love of the poet and an external recipient, living or dead, of that particular love.

Although Dante does not need a beloved in order to express his observations on love, it is evident that he does employ Beatrice as the object of his love. This usage is traditional in Provençal poetry as are certain characteristics which Dante attributes to his lady. For example, both Daniel and Dante describe the physical as well as the spiritual characteristics of their "midons." Daniel points out clearly that he has actually chosen his lady and procedes to enumerate her physical qualities. "e qan remir sa crin saura/e.1 cors q'a graile e nuou,/mais 1'am qe qui.m des Lucerna" (No. 56, 11. 19-21). Likewise, Dante refers to his infatuation with Beatrice as a child when he first decided to elect her as his beloved and carefully depicts the wonders of her physical beauty. Both poets also adhere to the medieval interest in the eyes as possible indications of love as the following two passages indicate. Daniel attests: 
Tant fo clara

ma prima lutz

d'eslir

lieis don cre. 1 cors los huoills.

(No. 57, 11. 18-21)

Dante follows the practice by saying, "Love is encompassed in my Lady's eyes/Whence she ennobles a11 she looks upon" (p. 60).

As Dante makes use of his 1ady's physical qualities in order to present his thoughts on the power of Platonic love, Daniel appreciates his lady's spiritual attributes even though he may be asking, in the same breath, for physical satisfaction.

Tant sai son pretz fin e certa per q'ieu no.m puosc virar aillors; per so fatz ieu que. 1 cors $m^{\prime}$ en dol, que qan sol's clau ni s'ajorna, eu non aus dir qui m'aflama.

$$
\text { (No. 58, 11. 23-7) }
$$

Besides referring to both the physical and mental traits of their ladies, the two poets also attatch a religious aura to the qualities of the loved ones. Daniel sets his lady on a saintly pedestal and addresses a prayer to her. In another poem he lights candles in church and offers masses in an endeavor to have "God on his side" as he courts his lady. However, the gracious 1 ady is threatened with hell if she does not comply with the poet's wishes. Indeed, it seems as if the religious aura is used by Daniel more as a means of flattering his loved one rather than with any intention of actually implying that the lady is truly endowed with saintly qualities.

As for Dante, the exact opposite is true. 
Anyone familiar with The Divine Comedy realizes that Beatrice is actually synonymous with love. However, even in La Vita Nuova which was written some twenty-five years before The Divine Comedy was completed, Beatrice has come to be the supreme symbol of love itself. In chapter XXIV of La Vita Nuova Dante clarifies Beatrice's symbolic value. Here he discusses his observation of Beatrice following one of her friends, Giovanna, through the streets of Florence.

One miracle after another came!

Love's words re-echo in my memory:

'She who precedes the other is called Spring, And she who is in my image has my name.' ( $p .72$ )

Yet Dante does not stop the analogy here. He, too, feels it important to attatch a, religious mystique to Beatrice and, by extension, to love. In the last poem in the book the poet's flight of fancy allows him to view the soul of Beatrice glorified in heaven. Beatrice has long before represented the poet-lover's salvation, and the divine qualities of her being inspire a nobility in all his thoughts and actions. Not only is he inspired to forgive his enemies, but his very body is permeated with divine grace.

And when this most gracious being actually bestowed the saving power of her salutation, I do not say that Love as an intermediary could dim for me such unendurable bliss but, almost by excess of sweetness, his influence was such that my body, which was utterly given over to his governance, often moved like a heavy, inanimate object. (p. 41)

Beatrice has, in fact, been canonized by her admirer, for Dante does not ascribe such sacred 
characteristics to her in order to persuade her to return his love. Instead, his "complaints" are only designed to expose the suffering that he has endured for love's sake whereas Arnaut Daniel laments because he cannot succeed in entering his lady's bedroom. Dante's vision of love as a lord, and a lord who is a deity, continues when he sanctifies his lady who is the ultimate expression of that love.

Love, the lover, and the beloved are three thematic concerns that Arnaut Daniel and Dante used to fashion two very different types of love poetry. The differences which result, however, must also be considered in the light of the two poets' attitudes toward their art. Both view their poetry as an intermediary between the lover and the loved one. In this sense, both also discuss their poetry within the poems themselves. Arnaut Daniel is quite conscious that he is creating a work of art to serve as a testimony of his love for his lady.

En cest sonet coind' e leri

fas motz e capuz et doli,

e seran verai e cert

qan n'aurai passat la lima.

$$
\text { (No. 56, 11. 1-4) }
$$

It goes without saying that Dante, too, was aware of his responsibility as an artist, for La Vita Nuova is principally a treatise on his method of writing poetry, an Ars Poetica, an explanation of his "new life" as an artist. On one occasion, Dante even addresses his poem and asks it to act on his behalf in the eyes of his lady.

It is, however, in the consideration of his art that Dante departs most from the Provençal tradition as exemplified by Arnaut Daniel, for Dante's art is a direct result of the extreme 
internalization of his emotions. It is only by attempting to analyze the depth of such internal emotion that Dante can endeavor to make a detailed psychoanalysis of what love really is as he does in chapter XX. Furthermore, when Dante deifies love and canonizes Beatrice, he is also raising his art itself to the height of perfection since he considers love the only subject truly worthy of poetic expression in the vernacular.

The first to write as a vernacular poet was moved to do so because he wished to make his verses intelligible to a lady who found it difficult to understand Latin. This is an argument against those who compose in rhyme on themes other than love, because this manner of composition was invented from the beginning for the purpose of writing of love. (p. 73)

For Dante, art itself is divine, and the artist is analogous to a pilgrim spirit who aspires to journey to the sacred shrine of the absolute in artistic perfection. The last sonnet in La Vita Nuova serves as the expression of this go $\overline{a l}$.

Beyond the widest of the circling spheres A sigh which leaves my heart aspires to move. A new celestial influence which Love Bestows on it by virtue of his tears Impels it ever upwards. As it nears Its goal of longing in the realms above The pilgrim spirit sees a vision of A soul in glory whom the host reveres. Gazing at her, it speaks of what it sees In subtle words I do not comprehend Within my heart forlorn which bids it tell. That noble one is named, I apprehend, For frequently it mentions Beatrice; 
This much, beloved ladies, I know well. (p. 99)

Thus, art, too, may transmit grace and salvation. The fact that Dante expends and develops the traditional themes of such poets as Arnaut Daniel does not make Dante any less original or any less a good poet. By the same token, Arnaut Daniel must be judged in the context of the social milieu in which he was writing-that of the court life in Southern France at the end of the twelfth century. Perhaps it is for this reason that Dante can praise Daniel for his poetry and place him in purgatory at the same time. It is significant that Daniel is found in the seventh and uppermost circle of purgatory where the lustful dwell awaiting the moment when their repentance will be fulfilled and they will be allowed to enter heaven for eternity. For had Dante situated Daniel in heaven, he would have definitely contradicted his carefully calculated attempt to elevate Platonic love, the beloved, and art itself to the realm of divine existence.

The University of Kansas 


\section{Notes}

${ }^{1}$ Dante, The Divine Comedy, trans, Laurence Binyon, ed. Paolo Milano (New York: The Viking Press, 1969), Canto XXVI, 11. 115-126.

2 All references made to Arnaut Daniel's poetry are taken from Introduction à l'Etude de I'Ancien Provença1, eds. Frank R. Hamlin, P.T. Ricketts, John Hathaway (Genève: Droz, 1967).

${ }^{3}$ A11 references made to La Vita Nuova are taken from Dante, La Vita Nuova, trans. Barbara Reynolds, eds. B. Radice and R. Baldick (Baltimore: Penguin Books, 1969). 